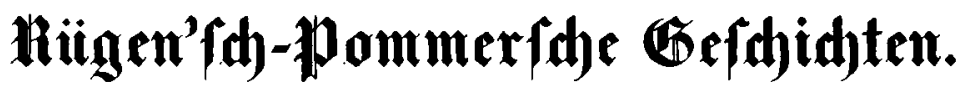





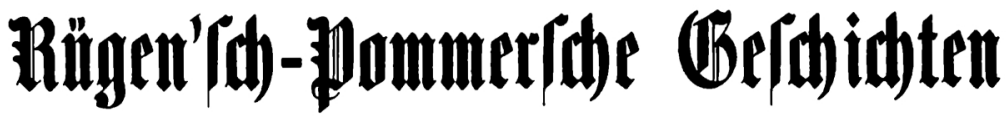

$\mathfrak{a} \mathfrak{z}$

fieben Sabrbunderten.

I.

\section{Pügen 1168.}

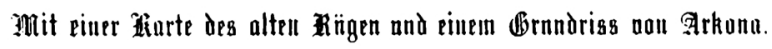

Bon

Ot to fod.

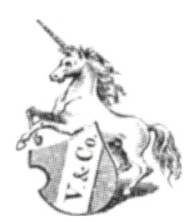

feipjig

Berlag bon Beit \& Eomp.

1861. 



\title{
Dem Andenken
}

\author{
besి Şerrn
}

\section{Wrof. Dr. S. (S., R. Mofegarten \\ und feiner Berdienfte}

um heimi/d)e \$pradpe, Riteratur und (be/didjte

in Dantbarer Erimnerung

gewiomet. 
